\title{
5.7 Кадровий потенціал як основний елемент в кадровій політиці підприємства
}

В ринкових умовах важливо забезпечити організацію кадрами в необхідній кількості і потрібної кваліфікації, що передбачає їі орієнтацію на зміни вимог до співробітників, інноваційні здібності керівників до вирішення конфліктів, вмінню створювати згуртовану команду і організовувати групову роботу. Управління персоналом починається з залучення людей на роботу. Кадровий потенціал доцільно формувати, розвивати і реалізовувати відповідно до цілей і завдань організації. При цьому кадрові служби повинні враховувати мотиваційні установки особистості і спиратися на дослідницьку базу, консультативну допомогу, управлінську інфраструктуру.

Проблемам кадрового забезпечення та мотивації праці присвячені дослідження М.І. Воєйкова, Ю.П. Кокіна, Н.Е. Титової, Т.Я. Четверняної, Л.С. Шаховської, Р.А. Яковлева. Окремі елементи мотивації персоналу докладно описані в працях С.А. Агапцова, В.В. Адамчука, Б.М. Генкіна, В.М. Соколинського, О.В. Ромашова та інших авторів.

Актуальність розвитку і удосконалення мотивації праці та іiі механізму постійно зростає, хоча реалії сьогодення створюють не однозначне ставлення до вирішення цих питань. Багато теоретичних питань мотивації трудової діяльності залишаються дискусійними й малодослідженими, а пропоновані практичні заходи є розрізненими й часто не пов'язаними між собою.

Основною метою роботи є дослідження основних теоретичних положень мотивації та стимулювання праці працівників підприємств в сучасних умовах їх функціонування, як головної складової кадрової політики.

Задоволенню потреби організації в трудових ресурсах на довготривалий період сприяє маркетинг персоналу, що включає дослідження і сегментування ринку робочої сили, вивчення якостей кандидатів і їх потреб, рекламу вакансій, виявлення і формування потенційних кандидатів в резерв всередині організації. 
Маркетинг персоналу може виступати в різних ролях: як головний принцип управління, орієнтований на ринок; в якості способу пошуку рішень відповідно до певної системою; як засіб досягнення переваг в конкурентній боротьбі; в якості напрямку стратегічного і оперативного планування персоналу.

Посередники здійснюють конфіденційний пошук працівників, надають професійне консультування, що полегшує роботу власного відділу кадрів. Крім того, завдяки компетентності посередника звужується сфера відбору з числа претендентів, кваліфікація яких заздалегідь відома.

Кадрова політика - сукупність способів впливу на персонал для досягнення цілей підприємства.

Кадрова політика повинна повністю відповідати концепції розвитку підприємства і в першу чергу передбачати формування стратегії управління персоналом, яка будується на систематичному аналізі внутрішнього i зовнішнього середовища.

Коли організація має в своєму розпорядженні засоби впливу на ситуацію $і$ здатна розробити антикризові кадрові програми, то вона проводить активну кадрову політику (якщо на підставі діагностування і прогнозування розвитку ситуації керівництво має можливість вплинути на неї, то дотримується раціональної політики; коли підприємство в програму розвитку включає плани кадрової роботи, не проаналізувавши ї з точки зору зміни ситуації (через відсутність коштів), то дотримується авантюристичної політики).

Робота 3 кадрами може зводитися до ліквідації негативних наслідків (пасивна політика). При цьому в організації відсутній прогноз потреб в працівниках, засобів оцінки праці і персоналу, діагностики кадрової ситуації в цілому.

Реактивна кадрова політика передбачає контроль симптом негативного стану в роботі з персоналом: виникнення конфліктних ситуацій, відсутність достатньо кваліфікованої робочої сили і мотивації до високопродуктивної праці. Превентивна політика спрямована на розробку програм розвитку організації, де відображаються короткостроковий і середньостроковий прогнози потреби в 
персоналі. У той же час через відсутність коштів керівництво не може вплинути на ситуацію, що склалася з кадрами.

Отже, кадрова політика повинна бути тісно пов'язана зі стратегією розвитку підприємства, враховувати його реальні фінансові можливості і зміни, що відбуваються в економіці. Стратегічний напрямок роботи кадрових служб полягає в забезпеченні умов конкурентоспроможності i довгострокового розвитку організації на основі регулювання відносин між адміністрацією та працівниками. Організації потрібно постійно відслідковувати зміни попиту на робочу силу з боку власних структурних підрозділів.

Кадрові служби повинні надавати допомогу в розвитку бізнесу за допомогою наймання висококваліфікованих працівників, планування кар'єри, оцінки виробничої діяльності, вдосконалення оплати праці.

Аналіз плинності кадрів необхідний для встановлення тенденцій призначень визначення попиту на нових співробітників, складання персональних графіків їх просування по службі, планування кар'єри, вирішення інших важливих питань. 3 числа співробітників, які пройшли навчання і тестування, необхідно відібрати тих працівників, які займуть вакантні посади.

Для підбору та розстановки кадрів використовується профільний метод, основу якого складає каталог характеристик (вимог), що пред'являються до конкретного працівника з урахуванням займаної ним посади. При цьому вимоги до посад включають спеціальні знання: освіту, професійний досвід, володіння іноземною мовою. У числі інших характеристик можуть бути управлінські якості, здатність до спільної роботи, відповідальність, цілеспрямованість, енергійність, підприємливість і т. п. Отже, профіль вимог призначений для визначення ступеня відповідності кваліфікаційних ознак співробітників певним посадам.

На практиці дуже важливо встановити ступінь відповідності якісних характеристик працівника вимогам займаної посади або робочого місця, для чого проводиться ділова оцінка персоналу. Разом 3 тим вона не обмежується тільки цим. Ділова оцінка персоналу реалізує три основні функції: адміністративну 
(прийняття керівництвом обгрунтованих рішень про підвищення заробітної плати, просуванні співробітника на посаді або про його звільнення), мотивуючу (стимулювання працівника до підвищення кваліфікації); інформаційну (інформування працівника про сильні і слабкі сторони його діяльності).

Систематична, продумана оцінка є важливим інструментом розвитку співробітників, підвищення ефективності роботи всієї організації, вирішення важливих виробничих завдань і конфліктних ситуацій. Ключовим питанням ділової оцінки співробітників організації $є$ розробка стандартів, 3 якими порівнюється їх діяльність. При цьому, як правило, оцінюються результативність праці, професійна поведінка і особисті якості.

В сучасних умовах кадрові служби повинні сприяти розвитку ділової активності організації, мобілізуючи резерви особистості кожного співробітника і акцентуючи увагу на самоосвіті і техніці групової роботи, тим самим надаючи допомогу керівникам вищої ланки управління у вирішенні ряду питань. При цьому основними напрямами кадрової політики повинні стати: проведення маркетингової діяльності в області персоналу, створення нових робочих місць 3 урахуванням впровадження сучасних технологій, підбір і розстановка кадрів, раціоналізація витрат на персонал, розробка програм зайнятості і т. п.

Організація буде досягати успіху, коли кадрові служби будуть краще вивчати ринок робочої сили і внутрішні джерела вибору з числа претендентів, займатися формуванням реального кадрового резерву i професійним просуванням співробітників, планувати витрати на персонал, сприяти забезпеченню соціально-психологічних умов в підрозділах.

Задоволенню потреби підприємства в трудових ресурсах на довготривалий період сприяє маркетинг персоналу, що включає дослідження і сегментацію ринку робочої сили, вивчення якостей кандидатів і їх потреб, рекламу вакансій, виявлення i формування резерву потенційних кандидатів. Саме тому в ринкових умовах важливо забезпечити підприємство кадрами у необхідній кількості і потрібної якості.

Кадровий потенціал будь-якого підприємства може істотно впливати на 
конкурентоспроможність підприємства тільки за умови, що всі основні складові технології роботи з персоналом - набір, адаптація, оцінка результатів праці, сучасні форми мотивації та організація праці, об’єднані в єдину програму.

Від кількісної і якісної збалансованості та рівня використання кадрового потенціалу значною мірою залежать високі кінцеві показники господарської діяльності, досягнення конкурентних переваг, можливості забезпечення сталого конкурентоспроможного розвитку підприємства та економічного зростання.

В свою чергу кадрова політика повинна повністю відповідати концепції розвитку підприємства і в першу чергу передбачати формування стратегії управління персоналом, яка будується на систематичному аналізі внутрішнього $\mathrm{i}$ зовнішнього середовища. Кадрова політика повинна бути тісно пов'язана iз стратегією розвитку підприємства, враховувати його реальні фінансові можливості і зміни, що відбуваються в економіці. Стратегічний напрям роботи кадрових служб полягає в забезпеченні умов конкурентоспроможності і довгострокового розвитку організації на основі регулювання відносин між адміністрацією і працівниками.

В сучасних умовах кадрові служби повинні сприяти розвитку ділової активності підприємства, мобілізуючи резерви особи кожного співробітника $\mathrm{i}$ акцентуючи увагу на самонавчанні і техніці групової роботи, тим самим надаючи допомоги керівникам вищої ланки управління в рішенні ряду питань. При цьому основними напрямами кадрової політики повинні стати: проведення маркетингової діяльності у області персоналу, створення нових робочих місць 3 урахуванням упровадження сучасних технологій, підбір і розстановка кадрів, раціоналізація витрат на персонал, розробка програм зайнятості і т.п.

Через відсутність методичної бази для детального дослідження якісних показників кадрового потенціалу та з метою виконання функцій у ринкових умовах господарювання, їхнього подальшого кількісного оцінювання $\epsilon$ необхідність розгляду таких показників (табл.5.7.1). 
Таблиця 5.7.1

Показники для аналізу кадрового потенціалу

\begin{tabular}{|c|c|c|c|}
\hline Показник & \begin{tabular}{|l} 
Умовне \\
позначення \\
\end{tabular} & \begin{tabular}{|l|} 
Формула для \\
розрахунку
\end{tabular} & Примітка \\
\hline $\begin{array}{l}\text { Продуктивність } \\
\text { праці }\end{array}$ & $\Pi$ & $\frac{B P}{U_{c p}}$ & $\begin{array}{l}\text { ВР - виручка від реалізації виробленої } \\
\text { продукції, тис. чол.; }\end{array}$ \\
\hline $\begin{array}{l}\text { Коефіцієнт } \\
\text { кадрового } \\
\text { забезпечення } \\
\end{array}$ & $K_{\text {кадр.забез }}$ & $\frac{\Psi_{\text {факт }}}{\Psi_{\text {nотр }}}$ & $\begin{array}{l}\text { Чср - середньоспискова чисельність } \\
\text { працівників, чол.; } \\
\text { Ч }_{\text {факт }} \text { фактична чисельність працюючих }\end{array}$ \\
\hline $\begin{array}{l}\text { Динаміка частки } \\
\text { працівників } 3 \\
\text { вищою освітою, } \\
\text { науковим } \\
\text { ступенем }\end{array}$ & $\Delta q_{B O}$ & $q_{B o}=\frac{\Psi_{B o}}{\Psi_{c p}}$ & 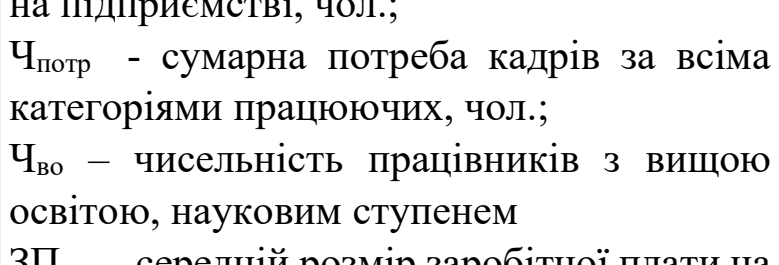 \\
\hline $\begin{array}{l}\text { Коефіцієнт } \\
\text { соціальної } \\
\text { захищеності кадрів }\end{array}$ & $K_{\text {cou. зах. }}$ & $\frac{3 \Pi_{c e p}}{3 \Pi_{\text {гал }}}$ & $\begin{array}{l}\text { 3П сер-середн1и розмір зароо1тно1 Плати на } \\
\text { підприємстві, грн; } \\
\text { ЗП гал - середній розмір заробітної плати в }\end{array}$ \\
\hline $\begin{array}{l}\text { Коефіцієнт } \\
\text { стабільності кадрів }\end{array}$ & $K_{\text {стаб }}$ & $1-\frac{\Psi_{3 b}}{\Psi_{c p}}$ & $\begin{array}{l}Ч_{\text {зв }} \text { - чисельність працівників, що } \\
\text { звільнились за аналізований період, чол.; }\end{array}$ \\
\hline $\begin{array}{l}\text { Коефіцієнт } \\
\text { мотивації } \\
\text { працівників }\end{array}$ & $K_{\text {мот }}$ & $\frac{\Phi_{\text {Mom }}}{\Phi_{3 n}}$ & 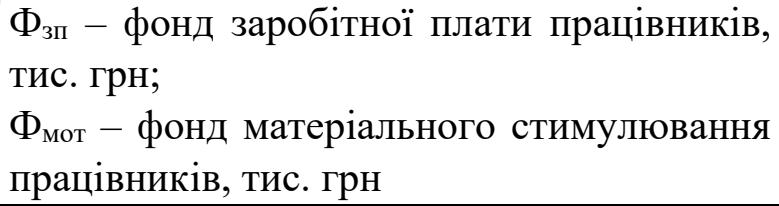 \\
\hline
\end{tabular}

Розглядаючи показник продуктивності праці, зокрема темпи його зміни, можна безпосередньо визначати зміну кадрового потенціалу.

Що стосується коефіцієнту стабільності кадрів, то низьке його значення свідчить про несприятливе внутрішнє середовище підприємства, про наявність негативних факторів, але водночас значення близьке до 1, може бути ознакою застою та відсутності конкуренції між працівниками.

Особливу увагу доцільно приділити рівню кваліфікації та мотивації працівників, а тому до переліку показників було включено: коефіцієнт соціальної захищеності кадрів, динаміка частки працівників з вищою освітою, науковим ступенем.

Як слідство, необхідно відзначити, що кадровий потенціал впливає на всі елементи структури конкурентного потенціалу підприємства шляхом:

визначення кількісних та якісних параметрів структури управління; зниження витрат на підготовку чи залучення висококваліфікованого 
персоналу;

забезпечення здатності виробити високотехнологічну продукцію; удосконалення механізмів мотивації праці, розробки об'єктивного маркетингового плану дій.

При цьому основними напрямами кадрової політики повинні стати: проведення маркетингової діяльності у області персоналу, створення нових робочих місць 3 урахуванням упровадження сучасних технологій, підбір i розстановка кадрів, раціоналізація витрат на персонал, розробка програм зайнятості і т.п. 